\title{
SRATEGI PENGELOLAAN SUMBER DAYA ALAM DESA PONGGOK
}

\author{
Ummi Zakiyah 1) *,Iqbal Aidar Idrus 2) \\ 1 Program Studi Ilmu Pemerintahan, Universitas 17 Agustus 1945 Jakarta. Jln. Sunter Permai \\ Raya No. 36 Jakarta Utara, 14350, Indonesia. \\ ${ }^{2}$ Program Studi Ilmu Pemerintahan, Universitas 17 Agustus 1945 Jakarta. Jln. Sunter Permai \\ Raya No. 36 Jakarta Utara, 14350, Indonesia.
}

* Korespondensi Penulis. E-mail: zakiyahmyamin@yahoo.co.id ; Tlpn. +62 87839841300

\begin{abstract}
Abstrak
Pembangunan desa bisa dilakukan dengan memberdayakan dan mengelola kekayaan sumber daya yang ada di desa. Sumber daya adalah sebuah aset yang harus dikelola dan dimanfaatkan dengan sebaik-baiknya untuk kesejahteraan masyarakat. Pemerintahan desa tentunya mempunyai peran penting dan juga harus mempunyai strategi sebagai alat untuk mencapai tujuan instansi maupun perusahaan dalam kaitannya dengan tujuan jangka panjang yang matang, dalam pengelolaan sumber daya atau asset desa. Tulisan ini bertujuan untuk mengetahui strategi Pemerintah Desa Ponggokdalam pengelolaan sumber daya alam. Strategi sebagai alat untuk mencapai tujuan instansi maupun perusahaan dalam kaitannya dengan tujuan jangka panjang Clausewitz (2013). Penelitian ini menggunakan metode kualitatif deskriptif, lokasi penelitian ini di Desa PonggokKecamatan Pulanharjo, Klaten Tawa Tengah. Teknik pengumpulan data dalam penilitian ini menggunakan metode, studi literature, observasi, dokumentasi. Hasil penelitian menunjukkan strategi yang dijalakan oleh Pemerintah Desa Ponggokyaitu: Pembenahan Umbul, membuat program one village one product dan pendirian Badan Usaha Milik Desa. Semua strategi yang dijalakan kemudian membuahkan hasil yang positif yang mengantarkan Desa Ponggokmenjadi desa yang mandiri dan sejahtera yang kemudian menjadi percontohan untuk desa-desa yang lain baik yang ada di Jawa Tengah maupun skala nasional
\end{abstract}

Kata kunci: Strategi, Pemerintahan Desa, Badan Usaha Milik Desa

\section{Strategy of Natural Resources Management of Ponggok Village}

\begin{abstract}
Village development can be done by empowering and managing the wealth of resources in the village. Resources are an asset that must be managed and utilized as well as possible for the welfare of the community. Village governance certainly has an important role and also must have a strategy as a tool to achieve the goals of agencies and companies in relation to long-term goals are mature, in the management of resources or asset villages. This paper aims to know the strategy of Ponggok Village Government in the management of natural resources. Strategy as a tool to achieve the goals of agencies and companies in relation to long-term goals Clausewitz (2013). This research uses descriptive qualitative method, the location of this research is in Ponggok Village, Pulanharjo Subdistrict, and Klaten Tawa Tengah. Technique of collecting data in this research use method, literature study, observation, documentation. The results of the research show that the strategies undertaken by the Government of Ponggok Village are: Umbul Upgrading, creating onevillage one product program and establishment of Village Owned Enterprise. All the strategies that are then led to positive results that lead Ponggok Village into an independent and prosperous village that later became a pilot for other villages both in Central Java and national scale.
\end{abstract}

Keywords: Strategy, Village Government, Village Owned Enterprise. 



\section{PENDAHULUAN}

Sejak diundangkanya UndangUndang Nomor 06 Tahun 2014 tentang Desa, telah memberikan hal baru dan perubahan kearah yang baik bagi tatanan pemerintahan desa secara khusus. Undang-Undang ini secara khusus tentang salah satu dari tugas pemerintah desa adalah mengatur, mengurus dan menfaatkan asset-aset desa, yang berkaitan dengan sumber daya alam dengan tujuan untuk kemajuan dan kesejahteraan desa. Sekaligus membuka keran pelaksanaan otonomi bagi desa sebesarbesarnya menjadi kekuatan bagi pemerintahan desa untuk mengurus dan mengatur serta menyelenggarakan rumah tangganya sendiri, termasuk di dalamnya pengelolaan dan pemanfaatan sumber daya alam yang ada.

Kekayaan alam yang dimiliki suatu desa adalah poin penting bagi desa dan bisa menjadi tempat pengumpulan pundipundi pemasukan apabila dikelola dengan baik dan benar. Salah satu wadah untuk pengelolaan sumber daya alam adalah dengan mendirikan badan usaha milik desa sebagai yang dilakukan oleh pemerintah Desa Ponggok Klaten Jawa tengah. Kemandirian dalam penyelenggaraan pemerintahan dan pembangunan desa merupakan suatu hal yang sangat penting. Kemandirian desa berarti mengedepankan kemampuan diri desa sebagai subyek dari penyelenggaraan pemerintahan dan pembangunan desa. Kemandirian desa sangat penting dilihat dari aspek filosofis, historis, dan strategis.

Keberhasilan pelaksanaan otonomi salah satunya dengan melihat keberhasilan pemerintah desa memberikan pelayanan kepada masyarakat, berhasil memberdayakan masyarakatnya untuk mampu membawa masyarakat desa kearah kehidupan yang lebih baik dan sejahtera dari sebelumnya. Selain itu pemberdayaan masyarakat juga harus diperhatikan yaitu sumberdaya alam dan pontensi yang dimiliki oleh desa agar bisa dimanfaatkan dan dikelola dengan baik yang dikemudian hari bisa memberikan dampak yang positif dan bisa mensejahterakan masyarakatnya. Untuk mencapai keberhasilan tersebut tentunya harus membutuhkan strategi dan perencanaan yang sangat matang dan harus dijalankan dengan baik pula.

Salah satu desa yang saat ini berhasil mengelola sumberdaya alam dan mengantarkan desa menjadi desa yang mandiri serta sejahtera adalah Desa Ponggok Kecamatan Pulanharjo Kabupaten Klaten Jawa Tengah. Desa ponngok yang dulunya saat jauh tertinggal secara perekonomian dan kemajuan masyarakat kini sudah berubah menjadi salah satu desa yang maju dan berhasil. Untuk mencapai keberhasilan dan kemajuan tersebut tentunya bukan sebuah perkara yang mudah harus ada perencanaan dan strategi yang matang sehingga menghasilkan sebuah produk kebijakan yang bagus dan nilai jual tinggi, serta bisa memberikan kesejahteraan bagi masyarakatnya. Keberhasilan ini tentunya tidak terlepas dari peran pemerintah desa tersebut, maka dari itu tulisan ini akan mengkaji tentang strategi pemerintah desa ponngok dalam pengelolaan sumberdaya alam melalui badan usaha milik desa.

Kreatifitas masyarakat dan apparat desa ponggok, Klaten Jawa tengah melalui pengelolaan sumber daya alam yang dimiliki berupa umbul yang kemudian 
menjadi obyek wisata umbul ponggok sebuah tempat permandian yang belakangan ini menarik wisatawan lokal dan mancanegara untuk berkunjung. Dahulunya tempat tersebut hanyalah tempat permandian biasa, namun sekarang disulap menjadi salah satu tempat rekreasi ternama di Jawa Tengah dan Indonesia. Keberadaan obyek wisata tersebut bisa meningkatkan pendapatan asli daerah yang dahulunya hanya 5 juta pertahun menjadi 6,5 miliar pertahun. Hal ini tentunya menarik perhatian mejadi sebuah perubahan besar yang terjadi dan tentunya juga membawa dampak yang besar juga bagi desa tersebut.

\section{METODE}

\section{Jenis Penelitian}

Jenis penelitian ini adalah kualitatif deskriptif. Metode kualitatif deskriptif merupakan prosedur pengumpulan data yang menghasilkan data deskriptif berupa kata-kata tertulis atau lisan dari orang-orang dan perilaku yang diamati. Penelitian ini dilakukan di Desa Ponggok Kecamatan Pulanharjo Kabupaten Klaten, Jawa Tengah.

\section{Target/Subjek Penelitian}

Adapun yang menjadi subyek dalam penelitian ini adalah Kepala Desa Ponggok, selaku penggasan untuk pembangunan desa dan Manajer BUMDES Desa Ponggok dan masyarakat Desa Ponggok selaku pengelola BUMDES.

\section{Prosedur}

Prosedur penelitian ini adalah pertama, pra survey melalui perlu dijabarkan menurut tipe penelitiannya. Penelitian ini adalh penelitian kualitatif deskriptif. Adapun cara yang dilakukan untuk memperoleh data adalah dengan melakukan pra survey, kemudian pengamatan situasi/observasi dan studi literature untuk melengkapi data.
Data, Intrumen, dan Teknik Pengumpulan Data

Data dalam penelitian ini adalah terdiri dari data primer dan data sekunder. Beberapa data telah dikelompok menjadi data primer dan juga data skunder sebagai berikut:

Data primer: adapun data yang dijadikan data primer dalam penelitian ini adalah data yang diperoleh dari hasil observasi dan pra survey seperti data kondisi wilayah, kondisi lingkungan.

Data sekunder: data sekunder dalam penelitian ini adalah data yang diperoleh dari hasil studi literatur dan dokumentasi seperti data dari media massa, video profil, dan naskah-naskah publikasi lainya.

\section{Teknik Analisis Data}

Teknik analisis data menggunakan Analisa data merupakan proses mencari dan menyusun secara sistematis. Data yang di dapatkan dari hasil observasi, studi literatur, maupun hasil dari observasi, dikelompokan kedalam kategori dan kemudian menjabarkan ke dalam unit-unit, menyusun kedalam pola dan diolah sedemikian rupa sehingga memperoleh kesimpulan berupa kebenaran yang dapat dipakai sebagai jawaban atas permasalahan-permaslahan yang diajukan dalam penelitian (M.Hum 2010:40). Teknik analisa data dalam penelitian ini menggunakan model Miles dan Heberman dalam Sugiyono (2014:334-335).

\section{HASIL DAN PEMBAHASAN Profil desa Ponggok}

Pemerintah desa dalam UndangUndang No. 6 tahun 2014 adalah kepala desa atau dengan sebutan lain dan dibantu oleh perangkat desa atau dengan 
penyebutan lain. Menurut hukum yang berlaku di Indonesia, Desa didefinisikan sebagai suatu kesatuan masyarakat hukum yang memiliki batas wilayah yang berwenang untuk mengatur dan mengurus urusan pemerintahan, kepentingan masyarakat setempat berdasarkan prakarsa masyarakat, hak asal usul dan atau hak tradisional yang diakui dan dihormati dalam sistem pemerintahan Negara Kesatuan Republik Indonesia, Ferina ( 2016).

Penyelenggaraan pemerintahan, Desa dipimpin oleh seorang Kepala Desa. Kepala Desa tersebut dipilih langsung oleh masyarakatnya dengan masa jabatan selama enam tahun dan dapat dipilih kembali hanya untuk satu kali pada masa jabatan berikutnya. Pemerintahan desa sebagai mana tercantum dalam UndangUndang desa bertugas untuk menyelenggarakan Pemerintahan Desa, melaksanakan Pembangunan Desa, pembinaan kemasyarakatan Desa, dan pemberdayaan masyarakat Desa. Dalam melaksanakan tugasnya, Kepala Desa dibantu oleh Sekertaris Desa dan beberapa Perangkat Desa. Menurut UU Nomor 6 Tahun 2014 tentang Desa dijelaskan bahwa, dalam penyelenggaraan Pemerintahan Desa, dibentuk Badan Permusyawaratan Desa (BPD). Badan ini berfungsi sebagai legislatif yang melakukan pengawasan terhadap kinerja Kepala Desa dan menetapkan peraturanperaturan bersama Kepala Desa, selain itu juga berfungsi menampung dan menyalurkan aspirasi masyarakat serta melindungi berbagai nilai dan adatistiadat yang ada pada masyarakat.

Desa Ponggok terletak di Kecamatan Pulanharjo Kabupaten Klaten Jawa Tengah. Secara geografis Desa Ponggok- terletak diantara dua gunung yang ada di Jawa Tengah yaitu, Gunung Merapi dan Gunung Merbabu, hal ini kemudian membuat desa ini kaya akan sumber daya mata air bersih yang siap untuk dikelola dan dikembangkan. Potensi alam yang ada di Desa Ponggok adalah berupa sumber mata air bersih atau warga disekitar menyebut dengan nama umbul. Adapun nama-nama umbul yang ada di Desa Ponggok diantaranya adalah Umbul Besuki, Umbul Sigedang, Umbul Ponggok, Umbul Kapilaler, Umbul Cokro. Semua Umbul yang ada di Desa Ponggok mempunyai peran dan fungsi serta mendatang keuntungan bagi warga desanya.

\section{Strategi Pengelolaan Sumber daya Alam}

Kata strategi berasal dari yunani, strategos (Stratos=militer $=$ og memimpin) yang berarti generalship atau sesuatu yang dikerjakan oleh para jendral perang dalam membuat rencana untuk memenangkan perang. Definsi tersebut juga dikemukakan oleh seorang ahli bernama Clauswts. Maka dari pada itu tidak mengherankan jika istilah strategi juga sering dipakai untuk perang dunia. Secara umum, kata strategi sering didefinisikan sebagi suatu cara untuk mencapai tujuan. Clausewitz yang dikutip Yunus (2016), mengartikan strategi merupakan rencana jangka panjang untuk mencapai tujuan. Strategi terdiri dari bberapa aktivitas penting yang perlu untuk mencapai sebuah tujuan.

Menurut Jackson, dalam Yunus (2016) mengatakan bahwa kata strategi dapat digunakan berbagai cara atau situasi: 
1. Strategy is a plan, a how, a means of getting from here to there

2. Strategy is a pottern in actions over time

3. Strategy is position, that is, reflects decisions toaffer prodeucts or service in particular markets.

4. Strategy is perspektifve, that is is, vision and direction.

Selanjutnya, Porter dalam Yunus (2016) mengatakan bahwa strategi adalah sekumpulan tindakan atau aktivitas yang berbeda untuk mengantarkan nilai unik.

Pembentukan strategi setidaknya terdiri dari tiga proses utama sebagai berikut:

1. Melakukan analisa situasi, evaluasi dan analisa pesaing; baik internal maupun eksternal; baik lingkungan mikro maupun makro.

2. Sejalan dengan penaksiran tersebut, tujuan dirumuskan. Tujuan ini kemudian harus bersifat parallel dalam rentang jangka pendek dan juga janga panjang yang termasuk didalamnya termuat peyusunan visi dan misi, serta tujuan organisasi ata perusahaan dengan baik.

Manajemen strategi menurut Wheelen \& Hugger (2008) adalah rangkaian langkah, keputusan dan tindakan perusahaan yang menentukan kinerja jangka panjang perusahaann. Manajemena strategi yang baik akan dapat membawa organisasi untuk bisa melaksanakan strateginya melalui perencanaan program, proses budgeting, sistem manajemen kinerja, perubahan pada struktur organisasi, serta manajeman program dan proyek. Selain itu juga yang diharus diperhatikan adalah bagaimana strategi dalam manajemen asset atau strategi manajemen sumber daya. Maka dari itu perlu untuk dikatahui juga teori-teori tentang manajemen aset sebagai berikut:

Strategi Manajemen Aset Menurut Chandler dalam Hayyuna, (2016) mendefinisikan strategi sebagai alat untuk mencapai tujuan instansi maupun perusahaan dalam kaitannya dengan tujuan jangka panjang, program tindak lanjut, serta prioritas alokasi sumber daya. Dengan keuangan. David J Hunger dan Thomas L. Wheelen yang dikutip oleh Joesron (2005, h. 18) menyatakan bahwa strategi manajemen memiliki dasar pokok meliputi:

a) Mengamati lingkungan (enviromental scanning) Mengamati lingkungan adalah kegiatan memonitoring faktor internal organisasi dan eksternal organisasi melalui konsep kekuatan (strength), kelemahan (weakness), kesempatan (opportunity) dan ancaman (threaths).

b) Penyusunan strategi (strategy formulation) Penyusunan strategi membahas tentang pengembangan rencana jangka panjang seperti penentuan visi dan misi, tujuan yang akan dicapai, mengembangkan strategi yang diwujudkan dalam suatu program maupun prosedur sebagai pedoman dalam melakukan kegiatan organisasi.

c) Pelaksanaan strategi (strategy implementation) Pelaksanaan strategi merupakan penerapan kebijakankebijakan yang telah ditentukan melalui pengembangan program, budget, dan prosedur. Pelaksanaan strategi pada setiap organisasi dapat berbeda-beda atau menyesuaikan dengan keadaan dari lingkungan organisasi tersebut.

d) Evaluasi atau kontrol Untuk mengetahui apakah suatu organisasi berjalan sesuai dengan strategi yang telah disusun maka, 
organisasi memerlukan sebuah pengawasan baik dari keanggotaan atau pihak internal maupun pihak ketiga atau eksternal.

\section{Pembenahan Umbul Ponggok}

Umbul Ponggok adalah sebuah kolam renang yang berasal dari sebuah sumber mata air bersih yang ada di Desa Ponggok. Umbul ponggok adalah umbul yang terbesar yang ada di Desa Ponggok. Saat ini Umbul Ponggok dimanfaatkan dan fungsikan sebagai salah satu destinasi wisata air dan juga sebagi sumber air bersih untuk masyarakat sekitarnya. Kolam alami ini sudah ada sejak zaman Belanda, dengan ukuran $50 \mathrm{x}$ 25 meter dan kedalaman rata-rata 1,5-2,6 meter. Umbul ini hadulunya adalah tempat pemandian biasaya bagi warga desa, baru tahun 2009 umbul ini mulai renovasi dan mulai dikenal masyarakat luas sekitar tahun 2014 sampai sekarang. Umbul Ponggok adalah salah satu yang paling besar mendatangkan keuntungan untuk desa tersebut.

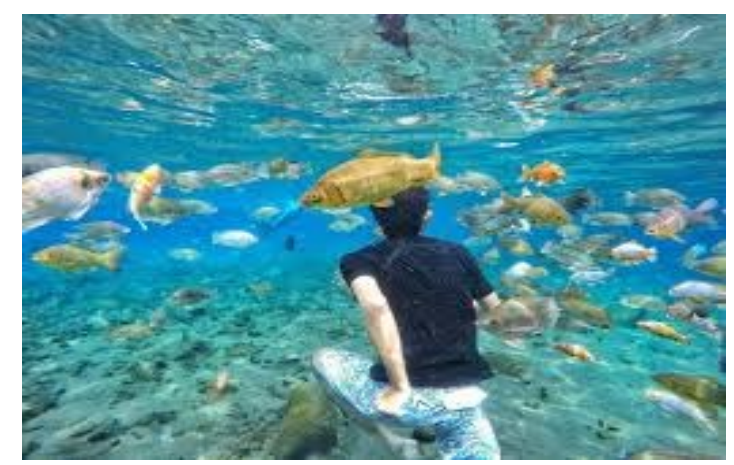

Gambar. 1 wisata Umbul Ponggok

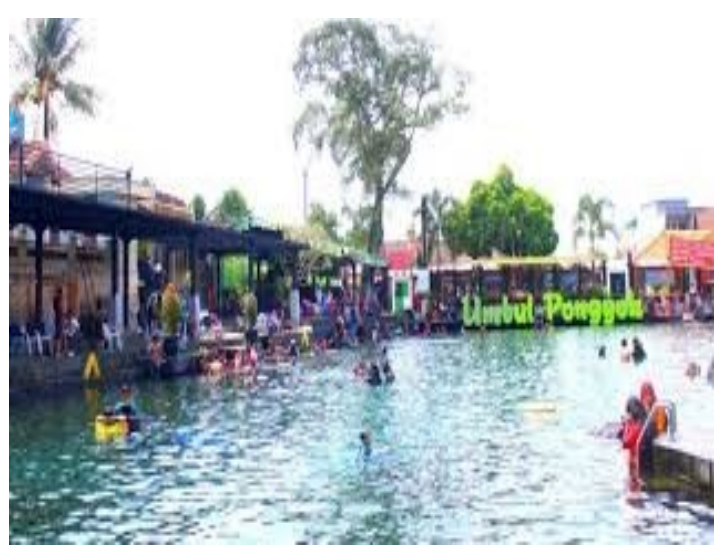

Gambar. 2 Mata Air Umbul Ponggok

Dari kedua gambar diatas menunjukkan pembenahan dari Umbul Ponggok sudah berhasil untuk mendatangkan wisatawan yang berkunjung dan juga bisa dimanfaatkan sumber air bersih bagi warga disekitaran Dusun Ponggok. Awalnya Umbul Ponggok hanyalah tempat pemadian biasa untuk masyarakat dan hanya mendatangkan PAD 5 Juta Pertahun. Namun setelah adanya perenovasian secara besar besar oleh pemerintah Desa Ponggokpada tahun 2016 umbul ini mendatang PAD menjadi 6,5 Miliar (Kompas : 2016). Peningkatan secara besar-besaran ini adalah bukti keberhasilan dari pemerintah Desa Ponggokdalam pengelolaan sumber daya yang dimiliki.

\section{Pembenahan Umbul Besuki}

Umbul basuki adalah yang berada sebelah barat dusun giringan, dibandingkan dengan umbul ponggok, umbul basuki relative lebih kecil dan juga dangkal denagn kedalaman rata-rata 1 meter. Umbul ini diperbaiki dan saat ini dimanfaatkan untuk sumber air bersih untuk daerah dusun giringan dan sekitarnya. Selain pemasok air bersih Umbul ini juga dimanfaatkan untuk irigasi sawah, segaimana letaknya yang berada didekat sekitaran persawahan. 
Jurnal Ilmu Pemerintahan, 2 (2), Oktober 2017 - 90

Ummi Zakiyah, Iqbal Aidar Idrus

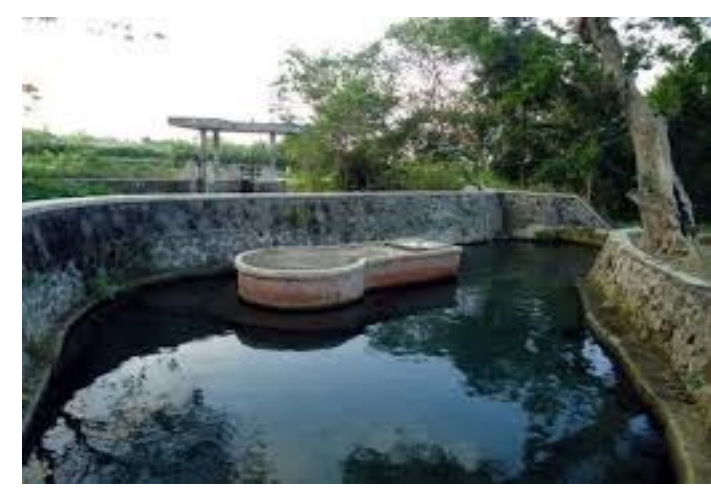

Gambar. 3 Umbul Besuki

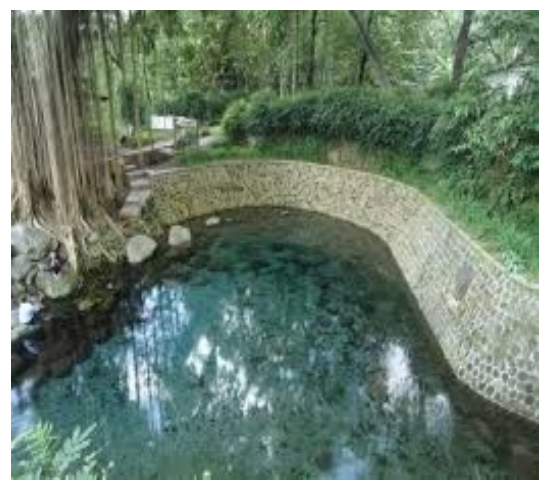

Gambar. 4 Umbul Besuki

\section{Pembenahan Umbul Sigedang}

Letak Umbul Sigedang berada di Dusun Umbul Sari sama seperti dengan umbul-umbul yang lainya umbul ini juga sudah perbaiki dan direvovasi. Saat ini umbul ini di fungsikan sebagai tempat penampungan air bersih bagi masyarakat Dusun Umbul Sari. Umbul Sigedang juga di manfaatkan oleh warga sebagi tempat permandian dan juga obyek wisata air. Selain itu, juga difungsikan juga untuk pembudidayaan ikan nila. Sebagaimana diketahui desa Ponggo adaah pemasok ikan Nila terbesar untuk daerah Klaten.

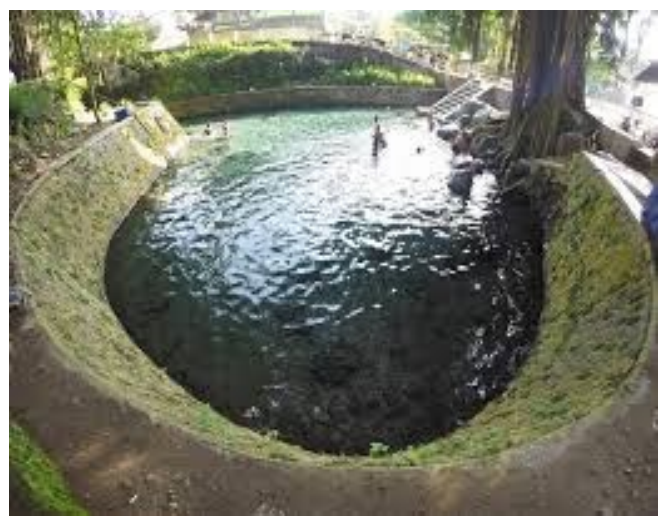

Gambar. 5. Umbul Sigedang

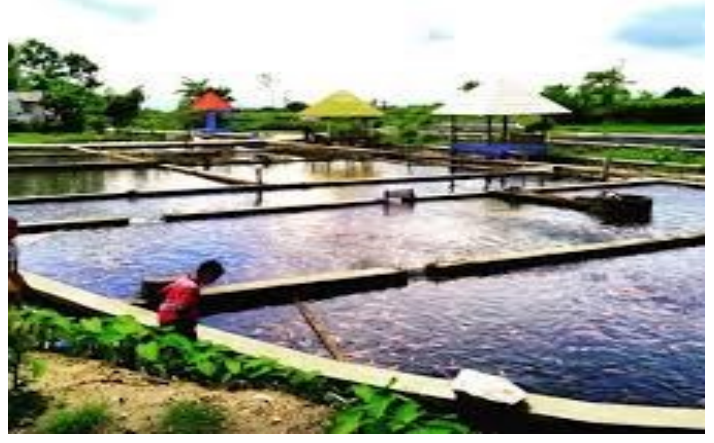

Gambar. 6 Budi Daya Ikan Nila

\section{Strategi One Village One Product}

Sejarah konsep one village one product (OVOP) ada gagasan untuk satu desa satu product pertama kali digagas oleh Gubenrur Oit Jepang yang bernama Morihiko hiramatsu tahun 1980 (Bumdes mandiritirta,2017). Kemudian seiring perkembangan zaman dan informasi banyak negara-negara di dunia yang menerapkan konsep OVOP dengan mengembangan beberapa program yang menjadi unggulan masing-masing negara tersebut. Indonesia saat ini melalui Kementerian Desa PDTT sudah mulai serius untuk mnegembangkan konsep OVOP yang merupakan menjadi pilar ke empat dari prioritas Kementerian Desa PDTT konsep ovop ini dikembangkan beringan dengan dengan dana desa.

Konsep OVOP ini juga menjadi strategi kedua yang dijalankan oleh Pemerintah Desa Ponggok dalam pengelolaan sumber daya alam yang dimiliki. Produk yang dipilih adalah olahan ikan Nila, melalui UKM nila murni. Kegiatan tersebut didampingi oleh ketua TP PKK Desa Ponggok. Adapun hasil produk dari olahan nila diubah menjadi berbagai macam jenis olahan makanan seperti, pangsit, cipir, pastel stik dari duri ikan nila. Produk-produk olahan tersebut dijual dan dipasarkan di stand-stand 
kuliner yang juga merupakan salah satu mitra dan bagaian dari usaha BUMDES, sekaligus menjadi oleh-oleh khas Desa Ponggok. Selain dipasarkan di Toko dan stand-stand lokal, Produk Nila murni juga saat di event-event ini sudah mulai mengikuti promosi keberbagai daerah seperti ke boyolali, juga sudah mulai diikutkan dalam event-event pameran kuliner yang diselenggarakan oleh Kemendes PDTT RI ataupun instansiinstasi lainya. Keberhasilan Pemerintahan Desa Ponggok dalam menjalankan strategi one village one product telah membawa dampak yang positif terhadap kemajuan dan kesejahteraan masyarakat terutama dalam mengurangi angka pengangguran di desa. Konsep OVOP tersebut sudah banyak menyerap tenaga kerja terutama kaum ibu-ibu yang kesehariannya hanya disibukan mengurus rumah, namun saat ini sudah diberdayakan dan bisa mempunyai penghasilan tambahan untuk keluarga.

\section{Pendirian Badan Usaha Milik desa}

Menurut Undang-Undang No 6 Tahun 2014 tentang Desa yang menjelaskan bahwa Badan Usaha Milik Desa (BUMDES) adalah badan usaha yang seluruh atau sebagaian modalnya dimiliki oleh desa melalui persyaratan secara langsung yang berasal dari kekayaan desa yang dipisahkan guna mengelola asset, jasa pelayanan, usaha lainya untuk sebesar-besarnya kesejahteraan masyarakat. BUM Desa merupakan badan usaha yang ditetapkan melalui peraturan desa hasil keputusan Musyawarah Desa. Badan usaha milik desa tersebut terdiri atas unit-unit usaha yang berbadan hukum seperti Perseroan Terbatas dan Lembaga Keuangan Mikro.
Menurut Pusat Kajian Dinamika Sistem Pembangunan FE Universitas Brawijaya dalam Hayyuna 2016, Badan Usaha Milik Desa (BUMDES) adalah sebagai berikut. "Lembaga usaha desa yang dikelola oleh masyarakat dan pemerintahan desa dalam upaya memperkuat perekonomian desa dan dibentuk berdasarkan kebutuhan dan potensi desa". Berdasarkan PERDA Kabupaten Gresik No 7 Tahun 2007 poin 13 tentang Pembentukan dan Pengelolaan Badan Usaha Milik Desa, pengertian Badan Usaha Milik Desa (BUMDES) adalah "Suatu Lembaga/Badan Perekonomian Desa yang dibentuk dan dimiliki oleh Pemerintah Desa, dikelola secara ekonomis, mandiri dan profesional dengan modal seluruhnya atau sebagian besar merupakan kekayaan Desa yang dipisahkan dan ditetapkan dalam Peraturan Desa". Adapun maksud dan tujuan pembentukan Badan Usaha Milik Desa menurut Bapemas Provinsi Jawa Timur (2009, h.4) adalah sebagai bentuk semangat tumbuh dan berkembangnya lembaga ekonomi desa menjadi badan usaha yang mampu menampung kegiatan ekonomi masyarakat, serta memberikan penguatan terhadap pendapatan desa. Selain itu, pembangunan masyarakat desa juga dapat ditingkatkan seiring dengan adanya penguatan terhadap pendapatan desa. Kemudian tujuan BUMDES untuk meningkatkan pendapatan desa dalam rangka pembangunan desa, mengembangkan potensi perekonomian di pedesaan, memberikan pelayanan terhadap kebutuhan masyarakat, memperoleh keuntungkan untuk memperkuat Pendapatan Asli Desa, meningkatkan pengelolaan aset desa yang ada. 


\section{Badan Usaha Milik Desa}

Pendiriaan BUMDes pada dasarnya membangun tradisi berdemokrasi di desa untuk mencapai derajat ekonomi masyarakat desa yang lebih tinggi. Dengan berbekal daftar inventarisasi potensi dan peta aset desa, forum musyawarah Desa Ponggok melakukan praktik deliberative demokrasi untuk menyepakati gagasan pengelolaan dan pemanfaatan aset-aset desa melalui BUMDes. Dengan pertimbangan yang matang Pemerintah Desa Ponggok mendirikan BUMDes pada tanggal 15 Desember 2009 berdasarkan keputusan yang dituangkan dalam Peraturan Desa No 06 Tahun 2009 dengan nama BUMDes Tirta Mandiri.

Tujuan pendirian BUMDes dalam pemberdayaan ekonomi masyarakat yaitu :

- Adanya fasilitasi pengembangan usaha produktif masyarakat desa.

- Kesempatan usaha lebih terbuka luas berikut dengan kesempatan kerja.

- Adanya berbagai media usaha yang luas dan variatif menyesuaikan potensi desa sesuai kemampuan dan kebutuhan masyarakat desa.

Tabel.2 Mitra BUMDES Tirta Mandiri

\begin{tabular}{|l|c|l|}
\hline No & $\begin{array}{c}\text { Jenis } \\
\text { Usaha }\end{array}$ & \multicolumn{1}{|c|}{ Keterangan } \\
\hline 1. & Kuliner & $\begin{array}{l}\text { BUMDesa Tirta Mandiri } \\
\text { membangun kios kuliner } \\
\text { yang disewakan kepada } \\
\text { warga sebagai bentuk } \\
\text { pemberdayaan ekonomi } \\
\text { warga. Kios kuliner ini } \\
\text { dibangun di 2 tempat } \\
\text { yaitu di dalam kompleks }\end{array}$ \\
\hline
\end{tabular}

\begin{tabular}{|l|l|l|}
\hline & & $\begin{array}{l}\text { Umbul Ponggok dan di } \\
\text { depan sompleks } \\
\text { Ponggok Ciblon. }\end{array}$ \\
\hline 2. & Wisata & $\begin{array}{l}\text { Merupakan sebuah } \\
\text { kolam alami yang } \\
\text { dikembangkan menjadi } \\
\text { Uisata snorkling yang } \\
\text { cukup terkenal di Klaten. }\end{array}$ \\
\hline 3. & $\begin{array}{l}\text { Toko } \\
\text { desa }\end{array}$ & $\begin{array}{l}\text { Usahanya adalah } \\
\text { penjualan barang-barang } \\
\text { kebutuhan rumah tangga } \\
\text { pada umumnya, dengan } \\
\text { nama toko desa "Sumber } \\
\text { Panguripan". Toko desa } \\
\text { memberikan pelayanan } \\
\text { kepada warga } \\
\text { masyarakat besa } \\
\text { Ponggokterutama bagi } \\
\text { warga yang memiliki } \\
\text { usaha kecil (UKM). }\end{array}$ \\
\hline
\end{tabular}

Sumber: Profil Bumdes Tirta Mandiri

Badan usaha yang ada di Desa Ponggok adalah berbasis mitra, yang terdiri dari beberapa usaha usaha kecil yang berada dibawah naungan atau pengawasan BUMDes. Tujuan dari sistem kemitraan agar pengelolaan sumber daya yang ada lebih sistematis dan manajemen pengelolaan ekonomi kerakyatan lebih baik demi keberlanjut dimasa mendatang secara terus menerus.

Keberadaan BUMDes akan meningkatkan kegiatan-kegiatan yang produktif seperti masyarakat dengan dibukanya kios-kios kuliner untuk masyarakat di lokasi obyek wisata Umbul Ponggok, serta menumbuh kembangkan iklim investasi bagi masyarakat, karena BUMDes sudah berhasil go public dengan menjual saham kepada masyarakat Ponggok untuk mendapatkan bagi hasil dari pengelolaan usaha BUMDes. 
Dari Tahun 2015 Sampai Tahun 2019 Ponggok akan mengembangkan semua obyek wisata yang dimiliki sehingga potensi dan asset desa bisa dimanfaatkan secara optimal untuk memperoleh pendapatan bagi masyarakat maupun pada dalam melangsungkan pembangunan secara berkelanjutan. Dengan mengelola satu obyek wisata saja yaitu Umbul Ponggok terbukti pada tahun 2014 pad yang diterima dari hasil usaha bumdes sudah sebesar Rp. 350.000.000,-. Data tersebut bisa membuktikan keberhasilan Desa Ponggok dalam menjalankan Usaha dan akan terus berupaya untuk meningkatkan pendapatan yang dihasilkan.

\section{SIMPULAN DAN SARAN}

\section{Simpulan}

Keberhasilan pelaksanaan otonomi salah satunya dengan melihat keberhasilan pemerintah desa memberikan pelayanan kepada masyarakat, berhasil memberdayakan masyarakatnya untuk mampu membawa masyarakat desa kearah kehidupan yang lebih baik dan sejahtera dari sebelumnya. Salah satu desa yang saat ini berhasil mengelola sumberdaya alam dan mengantarkan desa menjadi desa yang mandiri serta sejahtera adalah Desa Ponggok Kecamatan Pulanharjo Kabupaten Klaten Jawa Tengah. Desa Ponggok yang dulunya saat jauh tertinggal secara perekonomian dan kemajuan masyarakat kini sudah berubah menjadi salah satu desa yang maju dan berhasil. Untuk mencapai keberhasilan dan kemajuan tersebut tentunya bukan sebuah perkara yang mudah harus ada perencanaan dan strategi yang matang sehingga menghasilkan sebuah produk kebijakan yang bagus dan nilai jual tinggi, serta bisa memberikan kesejahteraan bagi masyarakatnya. Keberhasilan ini tentunya tidak terlepas dari peran pemerintah desa tersebut, maka dari itu tulisan ini akan mengkaji tentang strategi pemerintah desa ponngok dalam pengelolaan sumberdaya alam melalui badan usaha milik desa. Dimana dalam strategi pengelolaan sumber daya alam Desa Ponggokyaitu Pembenahan Umbul Ponggok sudah berhasil untuk mendatangkan wisatawan yang berkunjung dan juga bisa dimanfaatkan sumber air bersih bagi warga disekitaran Dusun Ponggok.

Awalnya Umbul Ponggok hanyalah tempat pemandian biasa untuk masyarakat dan hanya mendatangkan PAD 5 Juta Pertahun. Namun setelah adanya perenovasian secara besar besar oleh pemerintah Desa Ponggokpada tahun 2016 umbul ini mendatang PAD menjadi 6,5 Miliar, selanjutnya pembenahan Umbul Besuki ini diperbaiki dan saat ini dimanfaatkan untuk sumber air bersih untuk daerah dusun giringan dan sekitarnya. Selain pemasok air bersih Umbul ini juga dimanfaatkan untuk irigasi sawah, segaimana letaknya yang berada didekat sekitaran persawahan, begitu halnya dengan Pembenahan Umbul Sigedang juga di manfaatkan oleh warga sebagi tempat permandian dan juga obyek wisata air. Selain itu, juga difungsikan juga untuk pembudidayaan ikan nila dan strategi one village one produt telah membawa dampak yang positif terhadap kemajuan dan kesejahteraan masyarakat terutama dalam mengurangi angka pengangguran di desa. Konsep OVOP tersebut sudah banyak menyerap tenaga kerja terutama 
kaum ibu-ibu yang kesehariannya hanya disibukan mengurus rumah, namun saat ini sudah diberdayakan dan bisa mempunyai penghasilan tambahan untuk keluarga dan keberadaan BUMDes juga mendorong tumbuhnya kegiatan produktif masyarakat dengan dibukanya kios-kios kuliner untuk masyarakat di lokasi obyek wisata Umbul Ponggok, serta menumbuh kembangkan iklim investasi bagi masyarakat, karena BUMDes sudah berhasil go public dengan menjual saham kepada masyarakat Ponggok untuk mendapatkan bagi hasil dari pengelolaan usaha BUMDes.

\section{Saran}

Indonesia merupakan negeri yang berlimpah akan sumber daya alamnya, baik berupa benda mati maupun benda hidup yang berada di negeri kita ini yang dapat dimanfaatkan untuk memenuhi kebutuhan masyarakatnya. Terutama minyak bumi, gas alam, beberapa jenis barang tambang, mineral, hutan tropis dengan berbagai jenis kayu dan hasil hutannya, kekayaan laut, dan sebagainya. Apalagi dalam pengelolaan sumber daya alam Desa Ponggokbisa menjadi inspirasi untuk desa-desa lainya yang ada di beberapa provinsi di indonesia, yang mempunyai badan usaha milik desa dengan pendapatan yang luar biasa untuk menunjang PAD pemerintahan daerah di kabupaten tersebut dan membuka lapangan kerja untuk masyarakat sekitar sehingga dapat meningkatkan kesejahteraan masyarakat sekitar terkhusus di Desa PonggokKecamatan Pulanharjo Kabupaten Klaten, Jawa Tengah, sehingga tulisan ini bertujuan untuk memberikan informasi-informasi soal startegi pengelolaan sumber daya alam di desa yang sudah terbukti kualitas dan kuantitas dalam pengelolaanya untuk menjadi contoh desa-desa yang masih tertinggal jauh dari desa lainya.

\section{DAFTAR PUSTAKA}

Agunggunanto Edi Yusuf, Kushartono Edi Widodo. (2016). Pengembangan desa mandiri melalui pengelolaan bdan usaha milik desa (bumdes). Jurnal Dinamika Ekonomi dan Bisnis. 13 (1).

Alawi Muhlis Al. Contohlah Desa Ponggok, setahun hasilkan 6,5 miliar setahun. From:http://regional.kompas.com/ $\mathrm{read} / 2016 / 09 / 27 / 06320091 / \mathrm{cont}$ ohlah.desa.ponggok.setahun.hasilka n.rp.6.5.miliar.

Chintary Valentine dkk. 2016. PERAN PEMERINTAH DESA DALAM MENGELOLA BADAN USAHA MILIK DESA (BUMDES). Jurnal: Jurnal Ilmu Sosial Dan Politik, 5 (2).

Ferina, dkk. (2016). Tinjauan Kesiapan Pemrintah desa dalam implementasi peraturan menteri dalam negeri nomor 113 thun 2014 tentang pengelolaan keuangan desa (studi kasus pada pemerintah desa di Kabupaten Ogan Ilir, Jurnal Manajemen Bisnis Sriwijaya 14 (3).

Hayyuna, Dkk. Strategi Manajemen Aset BUMDES dalam Rangak meningkatkan pendapatan Desa. (Studi pada BUMDES di desa Sekapuk, Kecamatan Ujungpangkah, Kabupaten gresik. Jurnal Adminstrasi Publik 2 (1).

Hunger J. David \& Wheelen Thomas L. (2013). Manajemen strategis. Yogyakarta: Andi Yogyakarta.

Justi (2017). Badan Usaha Milik Desa (BUMDES) Desa Ponggok Hasilkan 6,5 miliar setahun. 
From:http://baperlitbang.kendalka b.go.id/component/content/article/ 14-artikel/257-badan-usaha-milikdesa-bumdes-desa-ponggokhasilkan-65-miliar-setahun.html

Moleong J Lexy 2012. Metodologi Penelitian Kualitatif. Bandung: Remaja Rosdakarya.

Sugianto 2017. Urgensi dan Kemandirian Desa dalam perspektif UndangUndang No tahun 2014. Yogyakarta: CV Budi Utama.

Sugioyono 2012. Metode Penelitian Kombinasi (mixed methods). Bandung: Alfa Beta.

Suharto Didik G. 2016. Membangun Kemandirian Desa Perbandingan UU No 5/1979, UU No 22/1999, UU No. 32/2004 serta Perspektif UU No. 6/Tahun 2014. Yogyakarta: Pustaka Pelajar.

Winasih Agus dkk (2016). Efektifitas pengembangan Desa wisata melalui kelembagaan dalam peningkatan sumber daya alam (SDA), Jurnal Ilmu Social Dan Ilmu Politik, 5(2).

Yunus Eddy. 2016. Manajemen strategis. Yogyakarta: CV. Andi Offset Yogyakarta.
Profil BUMDES Desa Ponggok. http://bumdestirtamandiri.co.id/

\section{PROFIL SINGKAT}

Ummi Zakiyah, S.IP., M.IP lahir 01 Mei 1991 di Desa Bukit Terak Simpang Teritip Bangka Barat. Lulus S1 Fisipol UMY Jurusan Ilmu Pemerintahan pada tahun 2013, lulus pada Program Pasca Sarjana UMY Jurusan Magister Ilmu Pemerintahan pada tahun 2016. Pada tahun 2016, Menjadi Staf Pengajar di Fakultas ilmu Sosial dan Ilmu Politik Universitas 17 Agustus 1945 Jakarta sampai sekarang.

Iqbal Aidar Idrus, S.IP., M.IP lahir 01 September 1992 di Kota Jambi. Lulus S1 Fisipol UNISMUH Jurusan Ilmu Pemerintahan pada tahun 2014, lulus pada Program Pasca Sarjana UMY Jurusan Magister Ilmu Pemerintahan pada tahun 2016. Pada tahun 2016, menjadi Staf Pengajar di Fakultas ilmu Sosial dan Ilmu Politik Universitas 17 Agustus 1945 Jakarta sampai sekarang. Menjadi pengelola Jurnal Of Government Prodi Ilmu Pemrintahan sejak 2016 sampai sekarang dan aktif sebagai Relawan Jurnal Indonesia Koorda RJI DKI Jakarta sejak Februari 2017. 